\title{
Environmental Attitude and Environmental Behavior of Catholic Colleges' Employees in Ilocos Sur, Philippines
}

\author{
Article by Damianus Abun ${ }^{1}$, Alfie P.Racoma ${ }^{2}$ \\ ${ }^{1} \mathrm{PhD}$ Faculty of the College of Business of Diviene Word College of Vigan, \\ Philippines \\ ${ }^{2}$ MST-Physics, Faculty of the college of Education of Divine Word College of \\ Vigan, Philippines \\ E-mail: frdamy@yahoo.com
}

\begin{abstract}
The study was intended to measure the understanding and attitudes of employees of Catholic Colleges in Ilocos Sur Province toward the environment and how such attitudes affect their behavior toward the environment. It was found that overall the employees were not certain related to their attitudes toward the environment and such ambivalent attitudes affect their behavior toward the environment. The study concludes that such ambivalent attitudes are caused by lack of understanding about environmental ethics. It is recommended therefore to improve awareness or understanding about natural environment through seminars on environment and to include environmental ethics in the curriculum.
\end{abstract}

Keywords: Environmental attitude, environmental behavior, anthropocentric attitude, human dominance over nature, eco-centric attitude, ecological behavior, conservation and population growth

\section{The problem}

\section{Rationale}

Environmental problems have become a serious concern of all human being on the planet. Why is it becoming serious concern? People have seen the connection between the environmental disaster and quality of human life. Quality of life has been affected by climate change. EPA (2016) mentions several impacts of climate change such as the increase of warming temperatures, changes in precipitation, and increases in the frequency of extreme weather events and the rising of sea levels. As a result, these affect the food that we eat, water we drink, the air we breathe, and the weather we experience. WHO (2016) estimated and predicted that between 2030 and 2050, the climate change is expected to cause approximately 250,000 additional deaths per year from malnutrition, diarrhea and heat stress. Such prediction causes alarm and immediate action. It cannot be ignored but it has to be solved but the question here is how can we solve it and from where do we start to solve the problem? Understanding the root cause of the problem is necessary for us to apply the correct solution to the environmental problem.

Many activities or programs have been initiated or introduced by the government and nongovernment agencies in order to address the climate change, global warming to prevent further deterioration of climate or global warming. Projects on tree planting and solar power have been introduced. However, these activities are not common yet, in the sense that not all people are planting trees and having a solar energy, instead of using ordinary fossil oil, while people in other parts of the world are still cutting trees and mining which causes the decrease of water resources. However, the root causes of the problem are not addressed. It shows that some countries understand and feel the importance of reducing the climate change particularly the developed countries and some countries do not see and feel the importance of reducing global warming in the case of developing countries. They are after industrialization and elevation of poverty. 
Solving climate change problems become uncertain is because of misunderstanding of the cause of climate change. A disturbing statement came from Scott Pruitt; the appointed head of EPA under President Donald Trump, as quoted by Daily Inquirer (2017) argued that CO2 is not global warming cause. Such statement goes against the scientific consensus that underpins Paris Agreement which more than 190 world leaders agree to lower emissions that lead to global warming. Misunderstanding on the cause of global warming causes a sporadic response to global climate change. The responses to climate change are not based on common consensus and mostly not based on the systematic and scientific study.

Solution of climate change problems starts from understanding the root cause of the problem. It is a fact that environmental problem is caused by human behaviors. If we go further, human behavior is caused by attitude or views toward certain object. If the person sees the object negatively or positively, it will affect the way how she/he relates to that object. Therefore, there can be several kinds of behaviors toward a certain object depending on the attitudes or views of the person toward that object. Those behaviors can be: respect, love, care or dominate, control or destroy. Going along with such argument, it is necessary that in order to solve environmental problems reviewing human attitude toward environment is a necessary. The concern here is do human beings understand the environment value and what particular attitude that really influence human behavior toward environment? That is the purpose of the study, to find out the level of understanding toward environment and their attitude of people toward environment and how they behave toward environment. This is to determine if understanding and attitude toward the environment really affects human behavior toward environment and what particular attitude that has more influence toward environmental behaviors.

\section{The purpose of the study}

The study is to determine the level of understanding and attitude of employees and measure the effects of such understanding and attitude toward environmental behavior. Consequently the result will be used for educational purposes to improve environmental awareness of the employees and consequently such awareness may lead to behavioral changes toward the environment. Further, the result of the study will be used to formulate school's policies related to garbage and energy management which is under the control of management. We believe that global warming is anthropocentric global warming; it is caused by human behavior. Human beings have been thinking only of themselves as center of the universe and looking at things around them as secondary, not important, except only if they serve the needs of human beings. Environmental consequences of such kind of attitude can be disastrous. The increase of weather temperature is getting uncontrollable, getting hotter every year. Thus the solution to reduce the global warming is going back to human beings themselves. Revisit again their attitudes and their behaviors toward the environment. By pointing out the relationship between human attitudes and human behaviors toward environment, the employees are expected to review again their attitudes toward environment and hopefully change their behavior into friendly environmental behaviors. Improving environmental attitudes and environmental behaviors of the employees will definitely bring some positive effects toward the students 'environmental attitude and behaviors. It is expected that the teachers will teach their students on how to see and to behave toward the environment. Environmental education aims to improve environmental attitudes of students toward the environment.

The study is not to problematize the role of anthropology and psychology in defining human behavior. The study just focuses on measuring the effect of human attitudes and environmental behaviors. It does not question whether human behavior is within the domain of psychology or anthropology. This study argues that behavioral changes usually happen when there are threats, fear, benefits, and attitudes. Thus consequently, the purpose of the study is to raise the awareness of the employees about the real danger of global warming and the fear for future generation. At the same time the study raises a hope about the benefits if 
human beings change their attitude and behavior toward the environment. That is the final end of this study, to change attitude and behavior toward the environment.

\section{Theoretical framework}

\section{Culture and attitude and behavior}

The anthropologists argue that the behavior of a person can tell many hidden things because through his/her behavior people can see what his culture is. The behavior is a manifestation of culture. People who are coming from different cultural background will have different views about things around them and definitely will have different reactions toward the same event. That is the power of culture. Culture is a means of explaining how one group of people behaves and another doesn't. Culture shapes the mind and the way how we think. Therefore culture does matter quite a bit on how we behave and how we think. According to Donald (2002) that culture has a significant influence on our brain functioning and even brain structure. Merlin holds that language has the biggest impact on brain structure but that culture influences brain functioning to a great extent as she writes:

The social environment includes many factors that impinge on development, from bonding and competitive stress to the social facilitation of learning. These can affect brain functioning in many ways, but usually they have no direct influence on functional brain architecture. However, symbolizing cultures own a direct path into our brains and affect the way major parts of the executive brain become wired up during development. This is the key idea behind the notion of deep enculturation... This process entails setting up the very complex hierarchies of cognitive demons (automatic programs) that ultimately establish the possibility of new forms of thought. Culture effectively wires up functional subsystems in the brain that would not otherwise exist.

Donald's view is somehow related to what Geert Hofstede as cited by Brown (1995). Geert Hofstede argued that culture is the collective programming of the human mind that distinguishes the members of one human group from those of another. Hofstede points out that culture is reflected in how people think, how people view things or attitude. We can distinguish people and their culture by just simply reading their attitude.

Amstrong (1996) in his examination of the cultural variables suggests that there is a relationship between cultural dimensions such as Uncertainty Avoidance and Individualism as prescribed by Hofstede's cultural dimensions and ethical perceptions. In other words, ethical perceptions of people vary depending on their cultural background. This finding supports the hypothetical linkage between the cultural environment and the perceived ethical problem variables posited in Hunt and Vitell's General Theory of Marketing Ethics (1986). Their theory indicates that that there is relationship between culture and ethical problems. The views and the values of people are formed by their cultural background. Example, one may say that bribery is immoral but another say that bribery is good.

In functionalist thinking, culture is considered a component of an integrated social system which promotes the effectiveness of the organization and the well-being of all its stakeholders. It refers culture as assumptions, beliefs, goals, knowledge and values that are shared by members of the society. British anthropologist Edward Burnett Tylor (1874 as cited by Racelis (2009) attempted to define culture as inclusively as possible. He described culture in the following way that "Culture or civilization, taken in its wide ethnographic sense, is that complex whole which includes knowledge, belief, art, morals, law, custom, and any other capabilities and habits acquired by man as a member of society". Culture represents the highinformation "ideal factors" in a system that exerts significant and partly independent influence on human events or human behaviors. When an individual is faced with an ethical dilemma, his or her value system will color the perception of the ethical ramifications of the situation. 
The theories that we have just cited above indicate that culture affects the way how people think, the way how people perceive things, their attitudes, their values, their beliefs and their behaviors. Similarly, another important factor that contributes to human behavior is their "core faith". This faith can be through religion, philosophy and culture or personal belief and often affects the way a person can behave. Many people believe some sort of belief in a higher power, which makes religion a large importance in society (Nones, 2012). It is only natural for something that plays such a large role in society to have an effect on human behavior (Spilka, 1996). Morals are another factor of core faith that affects the way a person behaves. Emotions connected to morals including shame, pride, and discomfort and these can change the way a person acts. Most importantly, shame and guilt have a large impact on behavior (Tangney, 2007).

Undeniably culture highly affects human behavior. The beliefs of certain cultures, values, and practices are taught to children from such a young age that they are greatly affected as they grow up. These beliefs, values and practices are taken into consideration throughout daily life, which leads to people from different cultures acting differently. These differences are able to alter the way different cultures and areas of the world interact and act (Triandis, 1994).Culture does not only affect the belief and values of people but it also affects their attitude. It appears to be seen as the culture affects the attitude and attitude affects the behavior of a person. An attitude is an expression of favor or disfavor toward a person, place, thing, or event. (Wyer, 1965). In this case, attitude does not only affect the behavior of a person to another person but it can also affect his/her behavior toward things or environment.

The interesting thing about an attitude and human beings is that it alters between each individual. Everyone has a different attitude towards different things. A main factor that determines attitude is likes and dislikes. The more one likes something or someone the more one is willing to open up and accept what they have to offer. When one doesn't like something, one is more likely to get defensive and shut down. Attitudes have a lot to do with the mind, attitude which highly relates to human behavior. The way a human behave will depends a lot on how they look at the situation and what they expect to gain from it (Kecmanovic, 1969). One can choose to be positive or to be negative. Positive attitudes are better than negative ones as negativity can bring on negative emotions that most of the time can be avoided. It is up to humans to make sure their attitudes positively reflect the behaviors they want to show. This can be done by assessing their attitudes and properly presenting them in society.

Definitely, attitude and behaviors are products of a culture. Change in attitude and behavior or belief or values require change in culture. Culture change can be difficult. It requires people to revisit again or reevaluate their beliefs, values, attitudes and only then they can change their behavior. It is often difficult for people to unlearn their old way of doing things, and to start performing the new behaviors consistently. However, it does not mean to say that culture cannot be changed; it can be changed if members of society are willing to change their attitude and behaviors, belief and values. A closer look at instinct driven behavior might help us understand this viewpoint better. For this, we can look at animal behavior, which is mostly controlled by instinct. In the case of humans, they can choose to ignore even such basic instincts, and put more thought and analysis in their behavior. They can also choose to do things in radically different ways. In this understanding; culture can be changed if people want to.

Environmental problems are considered anthropogenic environmental problems. It is called anthropogenic environmental problems because one of the main causes of environmental problem is the attitude of human beings toward the environment. Such attitude is rooted in the culture. One of the example is the Judeo-Christian culture as reflected in the Gen. 1:27-31, that after "God created the universe, He created man, male and female and blessed them and tell them to subdue the earth and have dominion over the fish of the sea, the birds of the air and living things that move on the earth". This teaching has been influencing the mind of people up to now and it has been taken by the capitalist as the basis of their argument against 
the environmentalists (Bricker, 2009). Such teaching sees the environment is seen as an object to be manipulated to serve the needs of human being. Human being is the center and everything around him is objects to serve his/her needs. Environment is recognized only in terms of their instrumental value but not their intrinsic value.

In relation to environmental problems, solving environmental problem cannot be addressed just by creating laws or rules that prohibit destroying the environment. Since problem is rooted in the culture, then solving environmental problem requires changing of culture or mindsets. Changing culture means changing people's belief, their views, value, perceive and only then they can change their attitude toward the environment or nature. Thus it needs to introduce new views about the environment that people need to adopt to replace the old view of environment.

Psychologists have long recognized that environmental problems are caused by maladaptive human behavior as pointed out by Maloney \& Ward, (1973). Supporting such idea, Oskamp (2000) accused human behavior as the culprit of the environmental problem. $\mathrm{He}$ argued that human behaviors or actions have caused many harmful and many possible irreversible changes to the environmental conditions that support life on earth. He then proposed that possible solution to environmental problem is to change humans' understanding and attitude toward the environment.

\section{Environmental attitude}

Environmental attitude is "the collection of beliefs, which affect, behavioural intentions a person holds regarding environmentally related activities or issues" (Schultz, Shriver, Tabanico, \& Khazian, 2004). Some studies conducted by Hines, Hungerford, \& Tomera, (1987); Kaiser, Wölfing, \& Fuhler, (1999), support such idea that environmental attitude has affected human behaviour toward the environment. However, dimensions of environmental attitude seem to have no common stand. According to Pierce \& Lovrich, (1980), Poortinga, Steg, \& Vlek, (2002), there are two dimensions of environmental attitude which are unconcerned about the environment at the low end and concerned for the environment at the high end. In this two-dimensional tradition, EA are classified as rooted in either a concern for all living things (ecocentric concern) or in a concern for humans (anthropocentric concern). Pierce \& Lovrich, 1980; Poortinga, Steg, \& Vlek, (2002), the proponent of two dimensions of environmental attitude, have used Thompson and Barton's (1994) scales to measure the human attitude toward environment. While Stern and Dietz's (1994) proposed three dimensions of environmental attitude which is based on the value orientation. Based on this value orientation, there are three environmental attitude and they are categorized as rooted in a concern for the self (egoistic concern), for other people (altruistic concern) or for the biosphere (biospheric concern). To measure the three dimensional environmental attitude, the proponent used Schwartz's (1992) value items.

However the present study will not use method used by those persons mentioned above but it will use the Environmental Attitude Inventory (EAI) developed by Milfont and Duckitt's (2006) original factor analytic scale. The method was used by Milfont and Duckitt's (2006) in their study on the Preservation and Utilization: Understanding the Structure of Environmental Attitudes. This EAI was to complete and to balance what have not been included on two and three dimensional environmental attitude scale developed by Thompson and Barton's (1994) and Schwartz's (1992). Milfont and Duckitt had categorized environmental attitude into twelve categories and they are enjoyment of nature, support for interventionist conservation policies, environmental movement activism, conservation motivated by anthropocentric concern, confidence in science and technology, environmental threat, altering nature, personal conservation behavior, human dominance over nature, eco-centric concern, and support for population growth policies. If Milfont and Duckitt (2006) did not classify environmental attitude and environmental behaviour, however, Hines, et al. (1986/1987) and Olsen (1981) pointed out that there are two types of environmental attitude used to predict ecological behavior and they are attitude toward the environment and attitude toward ecological 
behavior. Based on the EAI of Milfont and Duckitt (2006), the current study would classify the EAI into three categories and they are attitude toward environment, attitude toward ecological behavior and behavior toward environment. The reason why the researchers classify them because attitude and behaviour are two different factors, in which attitude precedes behaviour, in the sense that attitude influences the behaviour of a person.

Attitude is the how you think or feel about someone or something or it can be defined as learned predisposition to respond in a consistently favourable or unfavourable manner with respect to a given object (Eilam \& Trop, 2012). From such definition, it is clear that attitude has an object. A person has an attitude about something, be it a person or an object. In that case, attitude can be favorable and not favorable, can be positive or negative. In relation to our study, environment is considered as an object. As an object, the environment is constantly present and has multiple sub-objects which do not, as individual objects, represent the totality. Our attitude toward the environment will not be the same toward different sub-objects of environment. We have separate attitudes toward specific objects in the environment such as pine trees, a particular river, the Rocky Mountains, flower, animals, forest, etc. The environment is an expediential object, but no one experiences "the environment" as a whole, but rather separate distinct aspects of the environment (Heberlein, (n.d).

As I have mentioned earlier, that attitude can be favorable or not favorable, is because attitude has another components which are emotional (feeling) and cognitive components which refers to dispassionate facts and beliefs. Consequently attitude has some evaluation components. This may be very deep at an emotional level, where it is called affect. Thus, though not all, the object of attitude elicits emotional response, which may include like and dislike. This evaluative judgment such as, like or dislike, is defined as an attitude by Bern (1970) and Fishbein and Ajzen (1975). This attitude is based on evaluative beliefs and beliefs about a particular object. Attitude towards the environment commonly refers to environmental concern. Such concern may be classified as anthropocentric concern of environment and eco centric concern of the environment. Anthropocentric concern may include ssupport for conservation policies and protection of the environment motivated by anthropocentric concern for human welfare and gratification, versus support for such policies motivated by concern for nature and the environment as having value in themselves. While eco-centric concern may include a nostalgic concern and sense of emotional loss over environmental damage and loss, versus absence of any concern or regret over environmental damage.

\section{Anthropocentric attitude}

Centrism is a world view or the way how people view or look at things that place some particular value at the center. Environmental anthropocentrism is valuing nature because of material or physical benefits it can provide for humans. Nature is considered important if it can provide benefit for human beings. Human's need is at the center and everything else should serve human needs. As the Gale Encyclopedia of Science (2008) puts it that humans is considered to be the most important thing in the universe or on the planet. Anthropocentric attitude suggests that humans have greater intrinsic value than other species. Along such argument, anything that is useful for the fulfillment of human needs should be exploited. Such world view can have a devastating effect on the environment such as unsustainable environment or the extinction of living creatures. This kind of world view is the main culprit of violence against the nonhuman world.

Kortenkamp and Moore (2001) cautioned human beings the way they treat the nature because any kind of treatment can affect human beings. Therefore both call our attention that anthropocentric attitude deserves moral consideration because how nature is treated affects humans. Such call deserves our attention because when humans see the environment as purely in its instrumental value, then it can lead to a manipulative behavior toward environment. Both call humans to see nature in its intrinsic value, in the sense that nature has its own intrinsic value. Nature is good in itself. 


\section{Human dominance over nature attitude}

Our views toward nature are in fact influenced by culture because all of us are raised within certain culture and therefore our views toward nature are different ((Gibson, 2002). One component of culture is religion. The bible has formed our views toward nature such as Genesis, 1:26 which says, "Have dominion over the fish of the sea and over the birds of the air and over the cattle and over all the wild animals of the earth and over every creeping thing that creeps upon the earth" This text has been misunderstood because people have understood dominion as domination. As a result, many people have taken this text to justify human supremacy over nature and their manipulative behaviors. Such text indicates that the biblical mandate for human is to have dominion and not domination. However, the command to subdue should be understood within the context. The context was that human life was fragile in the face of threats from snakes and wild animals. Therefore, the command to "subdue" was meant to be able to restrain that which would bring them harm. This is according to the understanding of the word, "dominion". The Hebrew word for "dominion" does not mean domination or exploitation but it means to "take responsibility for" and "to protect" earth as a domain for which humans are responsible. In the context of Israel, the job of ruler was not to subdue or to dominate but a ruler who had dominion over Israel would be expected to be like a shepherd caring for and protecting the sheep. Rules is expected to take responsibility for the people in his realm, not to tyrannize or exploit them but to see that the people were protected and that justice was done for the poor, the widows, and the orphans. As such, "to have dominion over all the creatures" means that humans are to care for God's good creation. This text would be clearer if it is connected to Genesis, 2:15 which says "The Lord God took the human and put him in the Garden of Eden to till it and to keep or preserve it." From this text, the job of humans is to serve, preserve the land so that plants survive and thrive, not do dominate or exploit it.

Another source of our dominant behavior over nature comes from the belief that humans are not animals. Since they believe that they are not animals, and thus they claim dominance over the animal kingdom. Socio-biologists and primatologists on the other hand think otherwise. Humankind is closely related to apes; as humans share close to $98 \%$ of our genes with those of apes (Wilson 1975). Socio-evolutionary biologists might take this revelation to infer that human beings' relations with nature may be out of innate characters (Wright, 1994). However, even though evolutionary linkages to apes may lead to the conclusion that humans are just another ape, the majority of humans would not believe it. Instead they place humans as being above apes and apes as being just another lowly animal. The theory of evolution and any other linking of human beings to apes or animals has readily been challenged and denied by most religions (Gibson 2002). Religion still holds the primacy of human beings over nature as indicated in the bible texts that we have mentioned. Human being was created separately, independently and was tasked to have dominion and subdue the earth. Such biblical version has been taken by some to justify the position of man over nature. Human beings have generally connected animals with the wilderness.

\section{Eco-centric attitude}

The word, "eco-centrism" is originated from Greek word, "oikos" which means house, and "kentron" which means center. Eco-centrism is a term used in ecological study to denote a nature centered, not human centered as proposed by anthropocentrism. Eco-centrism denies the argument that only humans are the sole bearer of intrinsic value; possess greater intrinsic value than human nature. Eco-centrism argues that there is an equality of intrinsic value across human and non-human nature (Rowe, 1994). This argument is in line with the previous argument presented by Leopold (1949) who argued that all species, including human are a product of long evolutionary process and are inter-related in their life processes. Inter-relation between the two is a kind of recognition of the importance of non-human nature's contribution to the life of humans. In other words other non-human nature contributes to the life of humans and without it, humans cannot survive. As Spirkin (2016) pointed out that man 
is constantly aware of the influence of nature in the form of air he/she breaths, the water he/she drinks, the food he/she eats and the flow of energy and information. Further he argues that we are connected with nature by blood ties and we cannot live outside nature. This argument is in connection with eco-system argument that all living things interconnected.

The main question for eco-centrism therefore is the moral value of each part of the ecosystem. If we are thinking in eco-centric terms, we would save distinct species prior to human being which is opposed to the anthropocentric attitude. In the anthropocentric attitude, most people would instinctively save human lives prior to animals. However, the ecocentrism recognizes that all living beings have moral relevance because they are part of the eco-system, therefore the question would be: to what extent should we respect different species? (Johansson, 2012). Definitely, there is no one above the other because both, humans and non-human nature are interrelated and dependent on each other. Humans are steward of the environment and environment in return gives life to human beings.

\section{Attitude toward utilization of nature}

The exploitation of nature means the way how humans use the nature or natural resources for economic growth. Most of the time economic growth or profit becomes prime objective of a country or even a company to exploit the nature. Consequently, one can imagine the consequence of such concept to the nature that nature is simply as an object to serve the economic growth and profit. Such concept leads to environmental degradation and this was started during the industrialization era. Since industrialization era, extracting and processing of raw materials such as in mining, steam powers and machinery started. Nowadays, energy consumption rapidly increased. Today it is about $80 \%$ of the world's energy consumption is sustained by the extraction of fossil fuels which consists of oil, coal and gas (Planas, n.d).

Undeniably, our attitudes toward the utilization of nature depend on our views toward nature. Many believe that nature is meant for humans' welfare. We accept anthropocentric view toward nature that the existence of nature is for the fulfillment of human needs. By accepting such concept, we justify the exploitation of nature for human needs. Up to this day, eco-centric theory has not been popularized up to the grass root to counter such concept. Only if we adopt eco-centric view on the environment, we would not be free to use the environment at our pleasure because we need to respect the environment as having equal value with human beings.

\section{Attitude toward conservation policies}

According to Dictionary.com, the word conservation refers to an act of supervision of rivers, forest, and other natural resources in order to preserve and protect them through prudent management. However, since our discussion in this particular topic is related to natural environment, therefore conservation is the term to be used, not preservation because preservation refers to the protection of building, objects or landscape but not natural resources. The emphasis is on protection of the natural environment because natural resources need to be sustainable for future generation and for healthy climate. Sustainable environment can only be done through prudent management which can be done through creating policies that regulate the use of natural resources (National Park Service, n.d). The primary goal of the conservation policy is to pursue policies and measures that can help to improve the effectiveness and mitigates its harmful side-effects (Bostwana Environmental Information System, n.d). Those policies involve the regulation, protection and management of the natural resources that are important for the conservation of the environment. Such policies should be within the jurisdiction of the government because it has power to enforce the law.

The issue of conservation policy is not just a reaction to climate change but it is a concern of environmental ethics. The concern is about human beings' ethical relationship with the natural environment (Internet Encyclopedia of Philosophy, n.d). The primary question is what obligations do we have concerning the natural environment? It is our obligation is to maintain the health of the natural world, its fisheries, habitats and biological diversity because by 
maintaining its health will benefit human health in return. Its secondary focus is on materials conservation, including non-renewable resources such as metals, minerals and fossil fuels and energy conservation which is important to protect the natural world.

\section{Attitude toward population growth policy}

It cannot be denied that human beings are depending on the availability of food and the food that human enjoy is coming from natural resources. Therefore, natural resources are considered as the main supply of human needs. The relationship between population growth and environmental degradation is very clear. More people demand more resources. Problem would come when the supply is getting scarce and the population is growing. The natural resources can be depleted (Annenberg, n.d). It is government's responsibility to ensure that the natural resources are stable and sustained for a long period of time by creating policies. Population growth policy is becoming part of the natural resources management because population growth and its distribution have significant roles to play in the sustainability of the world's vast resources.

Mondal (n.d) identified several effects of population growth on our environment and they are: generation of waste, threat to biodiversity, strain on forest, urbanization, industrialization, land degradation, transport development, climatic change, productivity, and technology. It is along these concerns that population needs to be regulated in order to sustain the environment in the long run, for future generation.

\section{Environmental behaviour}

Environmental behaviour needs to be understood in the first place before we can point out its influence toward environment. The term "behaviour" is mostly intuitively understood and most psychological and sociological research into behaviour has not suggested definitions of the term (Eilam \& Trop, 2012). However, in the context of the present study, we understand the term as any active responsiveness to current environmental issues, believed to be proenvironmental by the person performing the response. In other words, human behaviour is about human act. Human act is deliberate act with a certain motive and purpose in mind. Thus environmental behaviour means how human beings response to the environmental problems.

Anthropocentric global warming is simply pointing to the fact that human actions have shaped the global climate. The root cause is not something outside of human beings themselves. Human beings are the main actors to be blamed. As Jarreau (2014) argued that it is our environmental behaviors in the end that either mitigate or contribute to global climate change today. According to him that our fundamental values, attitudes, beliefs and intentions are contributing factors to predicting our behaviors toward the environment. Such argument is emphasizing the fact that solving environmental problem, global climate is no other than solving human attitude and behaviors toward environment. Jarreau (2014) as he quoted from Rosa and Dietz (2012) argued that most releases of greenhouse gases are driven by consumption of goods and services by individuals, households and organizations, and the manufacturing, transport and waste disposal that underpins that consumption. Thus, in light of today's pressing environmental issues, the need to engage individuals and communities in positive environmental behaviors is more critical than ever.

\section{Environmental movement activism}

Environmental movement can be classified as scientific, social, and political movement for addressing environmental problems. The environmentalist groups advocate the sustainable management of resources and stewardship of the environment through changes in public policy and individual behavior in dealing with the environment. The concern of environmental movement is not just about conservation which is focusing on the wise and efficient use of natural resources for future generation but it is also demanding on a clean, safe, and beautiful environment as part of higher standard of living (Encyclopedia.com, n.d). 
Texila International Journal of Academic Research

Volume 4, Issue 1, June 2017

Environmental movement may not bear fruits if there are no supports coming from individuals and even the government. Largely the movement depends on the financial resources which may come from individual person or government budget. Montague (2012) lamented that environmental movement is not winning and it is because of failed policies of environmental funders. The funders have favored top-down elite strategies and have neglected to support a robust grassroots infrastructure. Such strategy is contradictory to the process of change. Change is not imposed from above but large scale change should be started from the grassroots.

\section{Personal conservation behavior}

Conservation behavior is becoming important when the natural resources are becoming scarce and the climate is getting warmer. By applying such behavior, the natural environment can be sustained in the long run. Most acknowledge that our behavior plays an important role in creating and resolving environmental challenges. This effort can only be done if people understand the importance of environment in relation to human life and the danger of climate change to the survival of natural environment and living things inside it. Education and communication play essential roles in creating a sustainable future.

It cannot be denied that human activities are often the direct cause of threats to wild species and habitats. Conserving our planet's biodiversity requires understanding which of our activities do harm to the environment and any living things in it, and developing and implementing sustainable practices and behaviors that will benefit both human populations and the nature that surrounds them (Conservation Breeding Specialist Group, n.d). Improving the awareness of people related to the effect of human behavior toward the environment can help them understand the necessity of the importance of conserving natural resources through the revision of their behavior.

\section{Conceptual framework}

In assessing the relationship between the human attitude and human behavior toward environment of private school employees in Ilocos Sur, the concept of the study revolve in the paradigm where independent variable is environmental attitude and under environmental attitude the study classifies attitude toward environment and attitude toward ecological behavior. While its dependent variable is human behavior and human behavior is classified into environmental movement activism and personal conservation behavior. The study would measure first environmental attitude toward environment and attitude toward ecological behavior. Second, it will measure how those attitudes affect the behavior toward environment. The paradigm reflects relationship between employees' environmental attitude and their behavior toward environment. Environmental attitudes are important predictor because they often, but not always, determine behavior that either increases or decreases environmental quality. 


\section{Independent variable dependent variable}

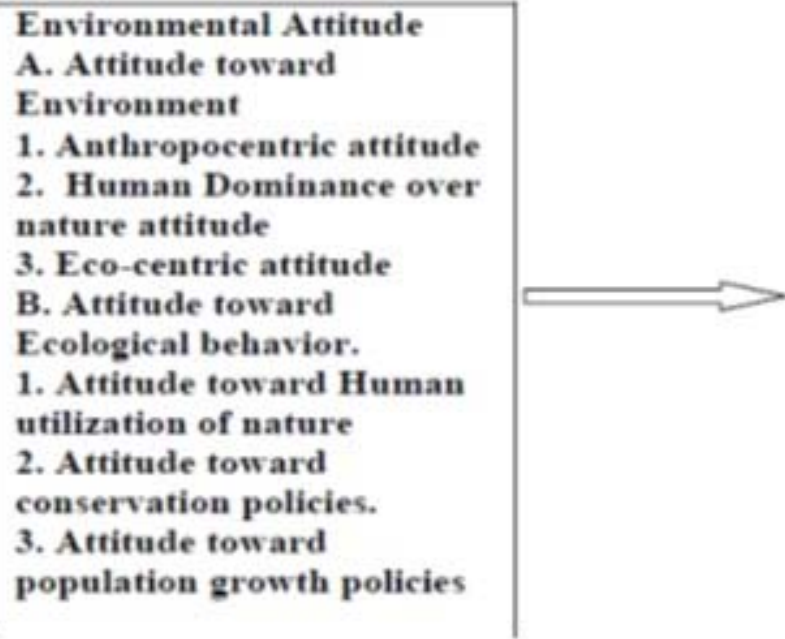

Environmental Behavior
1. Environmental Movement
activism.
2. Personal conservation
behaviors

\section{Statement of the problem}

The study aims to assess and determine the relationship between human attitude and human behavior toward the environment. It specifically seeks to answer the following questions:

1. What is the attitude of private Catholic school employees toward environment in terms of:

a. anthropocentric attitude,

b. Human dominance over nature attitude

c. Eco-centric attitude.

2. What is the attitude toward ecological behavior in terms of:

a. Attitude toward utilization of nature

b. Attitude toward conservation policies and

c. Attitude toward population growth policies.

3. What is the environmental behavior of employees of private Catholic school in terms of:

a. environmental movement activism?

b. Personal conservation behaviors.

4. Is there a relationship between environmental attitude and environmental behavior of Catholic private school employees of Ilocos Sur?

5. Is there a relationship between environmental attitude and attitude toward utilization of nature, personal conservation behavior and population growth policy?

6. Is there a relationship between attitude toward ecological behavior and environmental behavior?

\section{Assumptions}

The study is guided by the following assumptions:

1. The questionnaires used in the study are valid.

2. The employees of Catholic schools in Ilocos Sur are concerned with the environment.

3. Human attitude toward environment can affect human behavior toward environment.

4. The damage of environment is caused by human attitude and human behavior.

\section{Hypothesis}

The study is guided by the following hypothesis:

There is a relationship between attitude toward environment and human behavior toward environment. 
Texila International Journal of Academic Research

Volume 4, Issue 1, June 2017

\section{Scope and delimitation of the study}

The study is limited to measure the level of environmental attitude and environmental behavior of Catholic run private colleges' employees in Ilocos sure and to find out the relationship between environmental attitude and environmental behavior. The variables to be measured are anthropocentric attitude, human dominance over nature, human utilization of nature, eco-centric concern, attitude toward population growth policies, attitude toward conservation policies, environmental movement activism, and personal conservation behaviors.

The study is limited to Catholic private colleges that are operating within the province of Ilocos Sur, Philippines.

\section{Related literature and studies}

This chapter will present ideas taken from the books and studies related to human attitude and human behavior toward environment. Books related to human attitude and behavior towards environment may be limited compared to research studies on the relationship between human attitude and human behavior toward environment. The author tried his best to locate all books that are discussing the human attitude toward environment.

\section{Related literature}

\section{On human attitude toward environment}

Based on the library research, it seems hard to find many books discuss human attitude and human behavior toward environment. The topics are usually discussed under environmental psychology. Mostly the literatures that we discuss here are influenced by the environmental psychology. The first book that the author encountered was the book authored by Gifford and Sussman (2012). The title of the book is "Environmental Attitude". In that book Giffort \& Sussman (2012) argued that environmental attitudes are important because they often, but not always, determine behavior that either increases or decreases environmental quality. The two authors acknowledge to a certain extent that human attitude has some effects on the environment quality. Indirectly, these authors recognized that environmental attitude can be positive and negative. Positive environmental attitude are attitudes favorable to the preservation of environment and such attitude can improve the quality of environment, while negative attitudes are attitudes which are not favorable to the environment and such attitude can be harmful to the environment. In their presentation, Giffort and Sussman discussed attitude and environmental attitude independently. According to them, attitude has three elements and they are cognitive, affective and conative elements and while environmental attitude has preservation and utilization dimensions. In our view we can say that environmental attitudes involves cognitive, affective and conative elements too in which such attitude will influence the behavior, either to preserve or to utilize the environment.

"Respect for nature" is a categorical imperative or the order of the day for every human being to follow. Our respect for human being is relied on the fact that human being is endowed with dignity. Thus the dignity accorded to human beings obligates us to respect them unconditionally. Unconditional respect means that the respect accorded to the person is not because of his/her status, position, achievement and wealth as we usually do but it is because simply he/she is human being. Because of such dignity, we should not use human beings as means to an ends but human beings as endowed with reason are ends in themselves. The same line of thought is applied to the environment (Becker, 2009). Our respect for nature is just like our respect for human being. In the development of ethic of respect, the ethic of respect was not anchored only on human beings but it applies to all living things. Taylor (1986) was inspired by the Kantian theory of categorical imperative develop the same theory applied to all living organism. According to Taylor (1986) all living things or organism are ends in themselves and they are not different from each other and therefore they must be accorded by the same moral respect. Further Taylor emphasized that our respect to living 
organism is also relied on the concept that all living organism has not only intrinsic value which is dependent upon the appraiser but also intrinsic worth which is grounded in the objective properties of moral subjects, the most important of which is that they are teleological centers of life (Taylor, 1986).

Batchelor and Brown (1992) in their book, Buddhism and Ecology, presented the view of Buddhism about the environment. According to them, in the Buddhism, the practice of nonviolence makes all harming and killing an offense and thus it appears to leave an indelible mark on the treatment to animals and nature in general. According to the dictate of the precepts, harming the animals and vegetation is not acceptable and maybe considered as immoral. The Buddhism affirms life and do not kill. The practice of non-violence and compassion are expressed in the resistance of Buddha to the sacrifice of animals. There is no way of recovering of the life of those animals back to earth again. Though the investigation of Bachelor and Brown has not been connected to how the Buddhism followers behave toward environment but we believe that ideas and perceptions matters. The investigation of Bachelor and Brown into religion on environmental attitude helping us to convincingly say that culture, religion has strong influence on the formation of human attitude, human mind and human behaviour toward environment.

The concepts above just prove the existence of interdependence between attitude and behaviour. Nalukenge (2009) in his paper, Environmental Ethics is Key to Sustainability in a Contemporary Society argue that the way how humans interact with the environment depends on the ethics of a particular individual or society. The outcome of such interaction affects both quantity and quality of environment resources. He continued to argue that the sources of respect to the environment are based on instrumental and intrinsic value of the environment. Its instrumental and intrinsic value generates moral duty on the part of moral agent to protect it. Though such idea can be argued, however, such view enforces our belief that our attitude toward environment is really influenced by our values, beliefs or culture of the society. Cultures that enhance moral behaviour toward environment will definitely bring positive effect on the preservation of the environment. Thus Nalukenge (2009) further explained that culture, religion and indigenous ethics can be adopted to inspire new thinking that will ensure respect and compassion for other living things. However not all traditions are environmentally friendly.

In relation to the influence of attitude toward the treatment of environment, White (2008) in his book, "The Historical Roots of Our Ecological Crisis" argued that the source of ecological crisis is primarily is due to the Judeo-Christian tradition rooted in the anthropocentric attitude toward the environment. Its anthropocentric attitude is rooted in the book of Genesis 1: 26-28 which states: then God said: Let us make man in our image, after our likeness. Let them have dominion over the fish of the sea, the birds of the air, and the cattle, and over all the wild animals and all the creatures that crawl on the ground. God created man in his image, in the divine image he created him, male and female he created them. God bless them saying, "be fertile and multiply; fill the earth and subdue it. Have dominion over the fish of the sea, the birds of the air and all living things that move on the earth.

When this text is taken separately, people will understand immediately that human beings have received the marching order from God to use the earth as they wish which is included in order to subdue it. Thus, Bricker (2009) advises the reader of this biblical text, not to take it independently without referring it to the other text in the Genesis, 2:15 which states: "The Lord God then took the man and settled him in the Garden of Eden, to cultivate and care for it".

From Genesis 2:15, "God put human beings in charge of the earth to have dominion over the animals and to cultivate and care for the land". The text is not an absolute marching order to subdue the earth as human beings wish. There is a responsibility to cultivate and care for it. Problem arose from the beginning when people ignore Genesis 2:15 and take the texts that benefit human beings' immediate interest. 
The above argument really points out how culture has influenced the formation of human mind. Human beings' belief or religion definitely has strong influences over human behaviour, the way they deal with others and environment. White (2008) claimed that what people do about their environment depends on what they think about themselves in relation to things around them. The condition of environment is dependent on how people perceive the environment and such perception really depends on their culture, their religion.

Strengthening the position of White (2008), that culture or belief has influenced the human behaviour toward environment; Roach (2003) also argue that human beings have unconscious phantasy about the nature. She argued that nature has been associated with mother, however, mother will not always be a good mother, and there will also bad mother. She pointed out that unconscious phantasy about the mother shape our understanding about the reality. The world is like a screen onto which we project unconscious phantasies. We have seen that potent phantasies about the mother, both idealized and demonic, projected on the environment. She explained that to a certain degree, there is a legitimate metaphorical tie between nature and mother. These ties are reinforced — or one may even say exploited — by paranoid-schizoid phantasy that helps create the figures of Good and Bad Mother Nature. The intense and polarized passions of this position contribute to the emotional intensity and popular resonance of the Mother Nature imagery. Though the concept of Roach has not been validated through experiential study in the field as to the extent of the relationship between human beings' phantasies about their mothers and how they affect their behaviour toward environment, however, her position support our views in this study that belief, views, perception really affect our behaviour. Since nature is associated with mothers, our phantasy on idealized and demonic mothers will be projected into how we see and behave toward the environment.

On the economic side of human attitude, Hadfield (2009) argued that the idea of economic growth and sustainability and the ideology of progress through technology have brought prosperity for some over a few generations at the expense of long term degradation on a planetary scale. It cannot be denied that technology has brought prosperity to different parts of the world but at the same time, ideology of economic growth has been linked to a set of interlinked, impending, and long predicted, crises of the physical world such as resource depletion, water shortage, soil deterioration, the accumulation of non-degradable waste and climate change. The idea of development and sustainability has been proven to be unsustainable in the long run. The point of this argument is that the idea of economic growth without considering its effect toward the environment is the source of environmental problem or global warming that we are facing. Running after the projected economic growth often time blind the eyes to see the long term consequence. The concern of sustainable development which is good idea but unfortunately when it is operated under blind vision for the future can be a source of tragedy in the long run. It is under the threat of the current global situation of environmental degradation, climate change, economic instability and social disorder, Weber (2009) calls for new thinking and action. He suggested reviving cultural practices, which incorporate respect and co-existence with nature is one way of restoring the environment. It is a long such call, Schinkel (2009) calls for compulsory education on the environment and he recommended, which I may not agree with, a moderately anthropocentric view interpretation of ecological behaviours should be offered, supplemented by the notion of justice for nonhuman animals.

\section{On human behaviour toward environment}

According to Psychology Glossary (n.d), human behaviour refers to the full range of physical and emotional behaviour that humans engage in; biologically, socially, intellectually, etc. and are influenced by culture, attitudes, emotions, values, ethics, authority, rapport, persuasion, coercion and/or genetics. This type of behaviour is scientifically viewed as being without specific meaning, unlike social behaviour that is influenced by the expectations of others.

(http://www.alleydog.com/glossary/definition.php?term=Human\%20Behavior\#ixzz4Fb8ure7 
L). In such definition, it may be correct to say that one can be defined and identified through their behaviour because behaviours, after all, are not just the product of accidence but it is somehow planned Behaviours are reflections of what is inside the person: his/her values, attitudes, emotions, and moral values.

According to the theory of Planned Behaviour (Ijzen, 1991), behaviours are caused or influenced by the intention. The theory argues that the most proximal predictors of behaviour are behavioural intentions and intentions are influenced by several factors such as (a) the extent to which individual holds a favourable attitude toward the behaviour. Favourable attitude determines the intensity of the behaviour. Favourable attitude includes individual's values and beliefs about the outcome of the behaviour. In this case, values of the outcome influence the behaviour. (b). Subjective norms. This refers to a belief of what other people think the person should do or general social pressure. In other words, a person behaves in line with social expectations. (c.) The extent to which the individual perceives the behaviour at hand to be under his or her personal control (perceived behavioural control). This is related to self-efficacy in which the person believes in himself/herself to perform the behaviour. The latter relates to an individual's belief that their behaviour will successfully promote expected goals (Sawitri, Hadyanto \& Hadi, 2014). The Planned Behaviour Theory prove the point that we are going to pursue in this study that human behaviours are influenced by their intentions and their intentions are influenced by their attitude, the way how people see or perceive the objects or human beings. In line with the theory of Planned Behaviour, the Values-BeliefsNorms Theory also argues that prosocial behaviour is stimulated by activating norms of helping. These norms stem from three factors: (a) personal values, (b) beliefs that these values are under threat, and (c) beliefs that the individual can take action to reduce the threat and restore those values (Sawitri, Hadyanto \& Hadi, 2014).

Other social psychologists, Glanz and Rimer (1995) argue that individual behaviour is not just influenced by personal attitude and values but also other factors. They pointed out that individual, interpersonal, institutional, community and public policy factors influence individual behaviours. In terms of individual factor, knowledge, attitudes, belief and personality determines individual behaviour. These factors are unique to each person. According to Glanz and Rimer, the psychologist would focus on these items (knowledge, attitude, belief, personality style and disposition) to explain individual motivation. On the interpersonal factors, there are several determinants of individual behaviours and they are social identity, support and roles. Social identity refers to how people see themselves with respect to other people. Social background can also determine the behavior of individual person. Further, individual behavior can also be affected by the level of social support one has from people around them and the role of one has in the organization. The next level of determinant factor in individual behaviors is institutional factors where people work and this includes rules, regulations and informal structures. People behave according to what is allowed and not allowed by the rules of the organization. Besides institutional factors, another factor influences human behavior is the community. Community factors involve all of those influences, issues, and structures, which are a part of the general neighborhood, the general social environment in which people live. The last factor that stimulates human behavior is public policy. This refers to public regulation that promotes certain behavior. Usually people follow the rules to avoid penalty.

If Glanz and Rimer (1995) argued that internal and social factors influence individual factors, however, Banduras (1986), a social cognitive theorist in his book, "Social Cognitive Theory", argue that individual behaviors are not only driven by internal factors or forces but also by external factors. Internal factors may include what Glanz and Rimer (1995) called individual factors or in Bandura's term, personal factors which include knowledge of the person, drive, trait, attitude, personality and beliefs. While external factors refer to the environmental factors which represent situational influences and environment in which behavior is performed. 
Related to individual factors or personal factors as mentioned by Glanz \& Rimer and Bandura, Hoffman (2015) argued that there are five most powerful self-beliefs that ignite human behaviors and they are control belief, competency belief, value belief, goal orientation beliefs and epistemology belief. Control belief refers to our self-belief that we have control over our own destiny, not depending on others' help to reach our goal. Next is competency belief. It is our overall assessment of our capability to achieve the desired outcomes and that we have the skills and abilities to complete the task. While value beliefs refers to our assessment of the outcome the behavior if the outcome of such behavior will meet his standards, if it is important for him and cultural standards, if it is not violating the cultural standards. It is here people is reluctant to pursue certain behavior if he/he finds out that such behavior will not be so important for him and if the culture does not allow such behavior to happen. Another self- belief is goal-orientation belief. Goal orientation beliefs are related to the reasons why we pursue such behavior. Goal orientation represents the alleged purpose for engaging in learning or the reasons a particular performance target is chosen. Lastly is epistemology belief. This belief refers to the belief of the sources of knowledge. The epistemology belief argues that there are several ways of obtaining knowledge and information. Some people may belief that knowledge is fixed, there is only one way how things can be done, while others believe that there are many others ways of doing things, there are many alternatives. According to Hoffman (2015) these are the instrumental forces that drive and direct our behaviors. These are the tacit beliefs that we have about ourselves. These self-beliefs determine the direction and intensity of our motivated action. The beliefs determine what we do, how we do it, and how we see our accomplishments in relation to the rest of the world.

\section{Related studies}

The following related studies are the studies conducted by different researchers to measures the relationship between attitude and environmental behavior. These related studies are found to be relevant to support the theoretical foundation of this study but most of these studies are conducted outside of the Philippines.

Kirk (2010) conducted a study on "Sustainable Environment and Pro-Environmental Behaviour". A cross-sectional survey compares the pro-environmental behaviours, intentions, environmental knowledge, and pro-environmental orientation of occupants working in a traditionally designed building and occupants working in a LEED-ND certified building located on the University of Nebraska-Lincoln Campus. The study found that there was a visible increase in the pro-environmental variables for occupants working in a sustainable environment, however, based on the data analysis indicated that the difference were not statistically significant for any measured variables. But when it came to the environmental knowledge and environmental behaviour, the study found that there was a significant correlation between individual's environmental knowledge and pro-environmental behaviours, as well as between individual's pro-orientation and pro-environmental orientation.

Related to environmental behaviour, Lynn (2014) also conducted a study entitled, "Distinguishing Dimensions of Pro-Environmental Behaviour". The study concentrated on identifying dimensions of behaviour that are distinct in terms of the extent to which people act pro environmentally. Three dimensions were identified, relating to at-home, transport-related and purchasing behaviour. The correlation between behaviours in each dimension was explored and the characteristics and attitudes associated with the extent to which behaviour was pro-environmental in each dimension were compared.The study found that attitudes towards the environment were more strongly associated with at-home or purchasing behaviours than with transport-related behaviours. The findings have implications for the design of policies intended to influence behaviours with environmental impact and for marketing of pro-environmental behaviours. 
Basing on Aljen's theory of Planned Behavior Kaiser, Wolfing, and Fuhrer (1999) conducted a study on "Environmental Attitude and Ecological Behaviour". Three variables were measured and they were environmental knowledge, environmental values and ecological behaviour intention. The study wanted to find out the relationship between the environmental attitudes such as environmental knowledge, environmental values and how those attitudes affect the ecological behaviour. The study asked the question such as what determines an individual's ecological behaviour, actions which contribute toward environmental preservation and conservation or how can behaviour be changed in a more ecological direction. The study found that environmental attitude is a powerful predictor to ecological behaviour.

Related to ecological behaviour, Vlek and Steg (2007) argued that environmental quality and environmental sustainability really depend on the behaviour of human beings. Therefore, they are recommending that social and behavioural research is crucial for securing environmental sustainability and improving human living environment. They emphasized that environmental sustainability is key for human societies throughout the $21^{\text {st }}$ century's world because environmental sustainability would affect quality of life. Undoubtedly Kalantari, Fami, Ali Asadi and Mohammadi (2007) blamed behavior directly to the environmental problem. In their study entitled, "Investigating Factors Affecting Environmental Behavior of Urban Residents: A Case Study in Tehran City- Iran", argued that environmental problems such as air and water pollution, urban garbage and climate changes in urban areas are the results of human behavior. Only change in human behavior can reduce these environmental problems. Thus studying attitude and behavior of people is a precondition to change this situation. Their study confirm still common belief that attitude toward environment is affecting human behavior toward environment.

Kaiser, Ranney, Hartig and Bowler (1999) conducted a similar study to assess the ecological behavior, environmental attitude and feeling of responsibility for the environment and at the same time to measure the effect of environmental attitude toward ecological behavior of California college students. The study found that 45 to $50 \%$ of the ecological behavior intentions predicted $76 \%$ to $94 \%$ of one's ecological behavior. Further, the study found the relationship between environmental attitude and ecological behavior. The study argued that ecological behavior is influenced by environmental knowledge, environmental values and feeling of responsibility toward the environment. In line with ecological behavior, Kaiser, Doka, Hofsteter and Ranney (2003) also conducted a study to measure the effect of ecological behavior and its environmental consequences. The study concluded that different behaviors can differ markedly in their environmental consequences. Some behaviors have some significant impact, while others are almost negligible. Scott (1994) conducted a statewide survey of Pennsylvanians in 1990 and gathered data on residents' opinions about ideas contained in the new environmental paradigm (NEP) and behaviors engaged in that are environmentally protective. His study found that although Pennsylvanians expressed support for the NEP, however, they were not likely to engage in activities that contribute to environmental protection. Correlation analysis revealed that although support for the NEP was predictive of environmental behavior, the linkages were not strong. Various social characteristics were more predictive of environmentally oriented behaviors than supportive of the NEP.

Still on the environmental attitude, Biyo, Koech, and Manguriu (2015) conducted a study on "Environmental Attitude and Ecological Behaviour among Students: A case Study of Kibera and Kasarani Division in Nairobi Kenya". The authors emphasized the point of concern as the reason why they conducted such study. They argued that environmental degradation poses a major threat to the existence of humanity today both in rural and urban settlements. Out of such concern they conduct the study to establish the relationship between attitudes and level of participation in environmental activities amongst these two settlements in an urban area-Nairobi. The study involved a sample of three hundred and twenty secondary school students randomly selected from secondary schools in Kasarani and Kibera Divisions. 
Data was primarily collected using researcher developed questionnaires. The study established that there was no significant difference, attitude and level of participation in environmental activities of secondary school students in Kasarani and Kibera Divisions. It was also found out that there was a positive relationship between attitude and ecological behaviour. Singh and Gupta (2013) also conducted similar study in India on "Environmental Attitude and Ecological Behaviour in Indian Consumer" The purpose of the study was to explore and identify the components of environmental attitude that can drive the specific ecological behaviour of Indian consumers. Further, it defines environmental attitude components as moderators and investigates them as predictor of ecological behavior. Many of the components of the study are found to be significantly correlated inferring that consumers behave ecologically in specific manners depending on the formed attitude. Also, findings suggest that EA components work as predictors of EB. Further, developing a positive environmental attitude is a step to achieve sustainable environment.

\section{Methodology}

The nature of this study is a quantitative study. The nature of quantitative study is to use statistics to analyze and interpret the data. Therefore, this chapter presents the research design used in this study, data gathering instruments, population, locale of the study, data gathering procedures and statistical treatment of data.

\section{Research design}

Since the study is a quantitative research, thus, the study used descriptive method of research to assess the level of employees' attitude toward environment and employees' behavior toward environment. It describes what is. It involves the description, recording, analysis and interpretation based on the data gathered through statistics. This is a fact finding with adequate interpretation. It assesses, determines and reports the way things are. In other words, it describes the data that have been collected on research sample, describes "what is" about the data gathered.

In line with the current study, descriptive assessment and descriptive correlation method were deployed. The study assessed first the environmental and behavioral attitude of the employees toward environment and then how each attitude correlated to their behavior. This was to identify what the dominant environmental attitudes among employees were and what particular attitude does affect the behavior of employees toward environment.

\section{Locale of the study}

The locale of the study was Catholic Colleges in Ilocos Sur which include Divine Word College of Vigan, run by the Divine Word Missionaries Congregation and St. Paul College, run by the Daughters of St. Paul congregation. These colleges are within Metro Vigan, Ilocos Sur, Philippines.

\section{Population}

The population of the study was taken from the employees of these two colleges run by the religious congregations or organizations. Since the population of the study is small, so the total enumeration was used in which all employees of the four colleges were taken as the respondents of the study. Total enumeration was taken based on the judgment of the researcher to meet the objective of the study.

\section{Data gathering instruments}

The study utilized questionnaires. The questionnaires were distributed to employees of the two private colleges in Ilocos Sur which are located in Metro Vigan. The questionnaires were adopted from Environmental Attitude Inventory (EAI, Milfont \& Duckitt, 2005). From the EAI, the researcher selected the inventories related to the current study.

The questionnaires were consisted of three parts. First part was measuring the attitude toward the environment which was composed of anthropocentric attitude, human dominance 
over nature and eco-centric attitude. Second part was measuring the attitude toward ecological behavior which was also composed of attitude toward human utilization of nature, attitude toward conservation policies and attitude toward population growth policies. Third part was measuring the environmental behavior. This part is composed of two indicators which are environmental movement activism and personal conservation behaviors.

\title{
Data gathering procedures
}

In the process of data gathering, the researcher sent letters to the Presidents of the four colleges in Ilocos Sur, requesting the Presidents to allow the researcher to flow his questionnaires in his college. The researcher personally met the Presidents and employees and requested them to answer the questionnaires.

The retrieval of questionnaires was arranged between the President's representative and the researcher with the help of employees and faculty of the three colleges.

\section{Statistical treatment of data}

In consistent with the study as descriptive research, therefore descriptive statistics is used to measure the weighted mean and their correlations. Since the study was not only assessing the level of environmental attitude and behavior but also how the two variables were correlated, thus the study is using Pearson's $r$ or Product Moment Correlation Coefficient. This is to determine the strength of correlation between two interval and ratio data.

Frequency distribution and percentage was used to describe the profile of the employees the three colleges, while weighted mean was used to determine the level the environmental attitude and environmental behavior. The following ranges of values with their descriptive interpretation will be used:

\section{Statistical range descriptive interpretation overall descriptive rating}

\author{
4.21-5.00 Strongly Agree (SA) Very High \\ 3.41-4.20 Agree (A) High \\ 2.61-3.40 Uncertain/Undecided Uncertain / Undecided \\ 1.81-2.60 Disagree (D) Low \\ 1.00-1.80 Strongly Disagree (SD) Very Low
}

\section{Findings}

The aim of the study was to determine the understanding and attitude of employees toward the natural environment and how such attitudes affect their behavior toward the environment. Based on such aim, the statements of the problems were proposed and the findings are the following:

Problem 1a: What is the attitude of private Catholic school's employees toward environment in terms of anthropocentric attitude?

Table 1a. The environmental attitude of private Catholic school employees toward environment in terms of anthropocentric attitude

\begin{tabular}{|l|l|}
\hline & Mean \\
\hline $\begin{array}{l}\text { 1. One of the best things about recycling is that it saves } \\
\text { money }\end{array}$ & 4.42 \\
\hline $\begin{array}{l}\text { 2. The worst thing about the loss of the rain forest is that it } \\
\text { will restrict the development of new medicines }\end{array}$ & 3.84 \\
\hline $\begin{array}{l}\text { 3. One of the most important reasons to keep lakes and } \\
\text { rivers clean is so that people have a place to enjoy water } \\
\text { sports. }\end{array}$ & 3.73 \\
\hline
\end{tabular}


Texila International Journal of Academic Research

Volume 4, Issue 1, June 2017

\begin{tabular}{|l|l|}
\hline $\begin{array}{l}\text { 4. Nature is important because of what it can contribute to } \\
\text { the pleasure and welfare of humans. }\end{array}$ & 4.27 \\
\hline $\begin{array}{l}\text { 5. The thing that concerns me most about deforestation is } \\
\text { that there will not be enough lumber for future generation }\end{array}$ & 3.45 \\
\hline $\begin{array}{l}\text { 6. We would protect the environment for the well-being of } \\
\text { animals and for the well-being of humans }\end{array}$ & 4.48 \\
\hline $\begin{array}{l}\text { 7. Healthy planet is very important for human happiness } \\
\text { and human reproduction. }\end{array}$ & 4.40 \\
\hline $\begin{array}{l}\text { 8. Conservation is important for improving the quality of } \\
\text { life and people's standard of living }\end{array}$ & 4.41 \\
\hline $\begin{array}{l}\text { 9. We need to keep rivers and lake clean in order to protect } \\
\text { the environment and living creatures in it and } \\
\text { consequently contributing to human welfare. }\end{array}$ & 4.51 \\
\hline $\begin{array}{l}\text { 10. We should protect the environment because people's } \\
\text { lives are dependent on it. }\end{array}$ & 4.46 \\
\hline As a Whole & $\mathbf{4 . 2 0}$ \\
\hline
\end{tabular}

Based on the data presented, it was found that the attitude of employees toward the environment was anthropocentric which was determined by its mean score of $\mathbf{4 . 2 0}$ which is interpreted as agree. Anthropocentric attitude reveals that the environment has value only if it serves as instrument to the attainment of human needs. If it does not fulfill such functions, then it is considered to have no value.

Problem 1b: What is the attitude of private Catholic school's employees toward environment in terms of human dominance over nature attitude?

Table 2. Attitude toward human dominance over nature

\begin{tabular}{|l|l|}
\hline & Mean \\
\hline 1. Humans were meant to rule over the rest of nature. & 3.62 \\
\hline $\begin{array}{l}\text { 2. Human beings were created or evolved to dominate the } \\
\text { rest of nature. }\end{array}$ & 3.54 \\
\hline $\begin{array}{l}\text { 3. Plants and animals have no much right as humans to } \\
\text { exist. }\end{array}$ & 2.20 \\
\hline $\begin{array}{l}\text { 4. Plants and animals exist primarily to be used by } \\
\text { humans. }\end{array}$ & 3.03 \\
\hline $\begin{array}{l}\text { 5. Humans are playing more important role in preserving } \\
\text { the ecosystem compared to animals. }\end{array}$ & 3.48 \\
\hline $\begin{array}{l}\text { 6. Humans are no more important in nature than other } \\
\text { living things. }\end{array}$ & 2.31 \\
\hline 7. Nature exists primarily for human use. & 3.10 \\
\hline $\begin{array}{l}\text { 8. Nature in all its forms and manifestations should be } \\
\text { controlled by humans. }\end{array}$ & 2.96 \\
\hline $\begin{array}{l}\text { 9. I do not believe humans were created or evolved to } \\
\text { dominate the rest of nature. }\end{array}$ & 2.86 \\
\hline $\begin{array}{l}\text { 10. Humans are no more important than any other } \\
\text { species. }\end{array}$ & 2.33 \\
\hline As a Whole & $\mathbf{2 . 9 4}$ \\
\hline
\end{tabular}

As it is indicated in the computed mean, it was found that as a whole, human dominance over nature attitude was rated at $\mathbf{2 . 9 4}$ which are interpreted as uncertain or undecided. The employees were either agreeing or disagreeing toward the proposed attitude toward the 
environment. Such ambivalent attitude indicates that employees may not have certain knowledge or idea about the environmental ethics.

Problem 1c: What is the attitude of private Catholic school employees toward environment in terms of Eco-centric attitude?

Table 3. Eco-centric concern attitude

\begin{tabular}{|l|l|}
\hline & Mean \\
\hline $\begin{array}{l}\text { 1. The idea that nature is valuable for its own sake is naïve } \\
\text { and wrong. }\end{array}$ & 2.88 \\
\hline 2. It makes me sad to see natural environments destroyed. & 4.34 \\
\hline 3. Nature is valuable for its own sake. & 3.62 \\
\hline $\begin{array}{l}\text { 4. One of the worst things about overpopulation is that } \\
\text { many natural areas are getting destroyed. }\end{array}$ & 3.91 \\
\hline $\begin{array}{l}\text { 5. I do not believe that protecting the environment is an } \\
\text { important issue. }\end{array}$ & 1.96 \\
\hline $\begin{array}{l}\text { 6. Despite our special abilities humans are still subject to } \\
\text { the laws of nature }\end{array}$ & 4.02 \\
\hline 7. It makes me sad to see forest cleared for agriculture. & 3.76 \\
\hline $\begin{array}{l}\text { 8. It does not make me sad to see natural environment } \\
\text { destroyed. }\end{array}$ & 1.78 \\
\hline 9. I do not believe nature is valuable for its own sake. & 2.14 \\
\hline $\begin{array}{l}\text { 10. I do not get upset at the idea of forest being cleared for } \\
\text { agriculture. }\end{array}$ & 2.01 \\
\hline As a whole & $\mathbf{3 . 0 4}$ \\
\hline
\end{tabular}

As it was gleaned from the table, it was found that as a whole the eco-centric attitude of employees toward the environment was rated at $\mathbf{3 . 0 4}$ which are uncertain or undecided. The employees could not decide if they agree or disagree with the proposed attitude toward the environment. Such ambivalent attitude concludes that the employees have no certain idea or proper understanding with regard to the value of the environment whether the environment has its own value in itself or depending on its use to the human welfare.

Table 4. Summary table on attitude toward environment

\begin{tabular}{|l|l|}
\hline & Mean \\
\hline 1. Anthropocentric concern Attitude & 4.20 \\
\hline 2. Human dominance over nature attitude & 2.94 \\
\hline 3. Eco-centric concern attitude & 3.04 \\
\hline As a Whole & $\mathbf{3 . 3 9}$ \\
\hline
\end{tabular}

Overall, based on the computed data related to environmental attitude, it was found that environmental attitude was at $\mathbf{3 . 2 9}$ which are uncertain or undecided. The employees were neither agreeing nor disagreeing toward human dominance over nature and eco-centric value of nature. There was only one sub variable along environmental attitude, anthropocentric attitude, that was rated within $\mathbf{4 . 2 0}$ which is interpreted as agree. Employees valued the environment in terms of its usefulness for the welfare of the human beings. However, though they may agree, such agreement still indicated lack of knowledge about the value of the environment. Therefore, overall, employees have no enough knowledge or correct information related to the environmental ethics which discuss the value of natural environment.

Problem 2a: What is the attitude toward ecological behavior in terms of attitude toward utilization of nature? 
Texila International Journal of Academic Research

Volume 4, Issue 1, June 2017

Table 5. Attitude toward utilization of nature

\begin{tabular}{|l|l|}
\hline & Mean \\
\hline $\begin{array}{l}\text { 1. It is alright for humans to use nature as a resource for economic } \\
\text { purpose. }\end{array}$ & 3.47 \\
\hline $\begin{array}{l}\text { 2. Protecting people's job is more important than protecting the } \\
\text { environment. }\end{array}$ & 2.45 \\
\hline $\begin{array}{l}\text { 3. Humans do not have the right to damage the environment just to } \\
\text { get greater economic growth. }\end{array}$ & 3.86 \\
\hline $\begin{array}{l}\text { 4. People have been giving far too little attention to how humans' } \\
\text { progress has been damaging the environment. }\end{array}$ & 3.62 \\
\hline $\begin{array}{l}\text { 5. Protecting the environment is more important than protecting } \\
\text { economic growth. }\end{array}$ & 3.60 \\
\hline $\begin{array}{l}\text { 6. We should no longer use the nature as a resource for economic } \\
\text { purposes. }\end{array}$ & 3.00 \\
\hline $\begin{array}{l}\text { 7. Protecting the environment is more important than protecting } \\
\text { peoples' jobs. }\end{array}$ & 3.38 \\
\hline 8. In order to protect the environment, we need economic growth. & 3.11 \\
\hline 9. The question of the environment is secondary to economic growth. & 3.06 \\
\hline $\begin{array}{l}\text { 10. The benefits of modern consumer products are more important } \\
\text { than the pollution that results from their production and use. }\end{array}$ & 2.54 \\
\hline As A Whole & $\mathbf{3 . 2 1}$ \\
\hline
\end{tabular}

Based on the data gathered and computed mean, it was found that attitude toward ecological behavior of employees in terms of attitude toward the utilization of nature was evaluated within the mean of $\mathbf{3 . 2 1}$ which is uncertain or undecided. The employees seemed to have no clear understanding or idea about how the natural environment should be used or treated. The employees were not able to take a stand whether to agree or disagree to the proposed attitude toward the utilization of nature. Such ambivalence again points out the fact about the lack of understanding of employees toward the environment and how human should use the environment.

Problem 2b: What is the attitude toward ecological behavior of employees in terms of attitude toward conservation policies?

Table 6. Attitude toward conservation policy

\begin{tabular}{|l|l|}
\hline & Mean \\
\hline $\begin{array}{l}\text { 1. Industry should be required to use recycled materials even when } \\
\text { this costs more than making the same products from new raw } \\
\text { materials. }\end{array}$ & 3.93 \\
\hline $\begin{array}{l}\text { 2. Government should control the rate at which raw materials are } \\
\text { used to ensure that they last as long as possible. }\end{array}$ & 3.98 \\
\hline $\begin{array}{l}\text { 3. Controls should be placed on industry to protect the environment } \\
\text { from pollution; even it means things will cost more. }\end{array}$ & 3.92 \\
\hline $\begin{array}{l}\text { 4. People in developed societies are going to have to adopt a more } \\
\text { conserving lifestyle in the future. }\end{array}$ & 3.94 \\
\hline $\begin{array}{l}\text { 5. The government should give generous financial support to } \\
\text { research related to the development of alternative energy sources, } \\
\text { such as solar energy. }\end{array}$ & 4.05 \\
\hline $\begin{array}{l}\text { 6. I do not think people in developed societies are going to have to } \\
\text { adopt a more conserving lifestyle in the future. }\end{array}$ & 2.92 \\
\hline $\begin{array}{l}\text { 7. Industries should be able to use raw materials rather than recycled } \\
\text { ones if this leads to lower prices and costs, even if it means the raw } \\
\text { materials will eventually be used up. }\end{array}$ & 3.04 \\
\hline
\end{tabular}




\begin{tabular}{|l|l|}
\hline $\begin{array}{l}\text { 8. It is wrong for government to try and compel business and } \\
\text { industry to put conservation before producing goods in the most } \\
\text { efficient and cost effective manner. }\end{array}$ & 2.87 \\
\hline $\begin{array}{l}\text { 9. I am completely opposed to measures that would force industry to } \\
\text { use recycled materials if this would make products more expensive. }\end{array}$ & 2.85 \\
\hline $\begin{array}{l}\text { 10. I am opposed to government controlling and regulating the way } \\
\text { raw materials are. }\end{array}$ & 2.75 \\
\hline As a Whole & $\mathbf{3 . 4 2}$ \\
\hline
\end{tabular}

As it was shown in the computation table, as a whole, the computed mean of attitude toward ecological behavior of employees in terms of attitude toward conservation policy was 3.42 which is interpreted as agree. Employees agreed to the proposed attitude toward ecological behavior. This indicates that employees have understood and have certain knowledge about the importance of conservation policies to protect the environment.

Problem 2c: What is the attitude toward ecological behavior of employees in terms of attitude toward population growth policies?

Table 7. Attitude toward Population Growth Policy

\begin{tabular}{|l|l|}
\hline & Mean \\
\hline 1. We should strive the goal of "zero population growth". & 2.95 \\
\hline 2. The idea that we should control the population growth is wrong. & 2.97 \\
\hline $\begin{array}{l}\text { 3. Families should be encouraged to limit themselves to two children or } \\
\text { less. }\end{array}$ & 3.03 \\
\hline $\begin{array}{l}\text { 4. A married couple should have as many children as they wish, as long as } \\
\text { they can adequately provide for them. }\end{array}$ & 3.66 \\
\hline $\begin{array}{l}\text { 5. Our government should educate people concerning the importance of } \\
\text { having two children or less. }\end{array}$ & 3.61 \\
\hline 6. We should never put limits on the number of children a couple can have. & 3.38 \\
\hline 7. People who say over population is a problem is completely incorrect. & 2.99 \\
\hline 8. The world would be better off if the population stop growing. & 2.74 \\
\hline $\begin{array}{l}\text { 9. We would be better off if we dramatically reduced the number of people } \\
\text { on earth. }\end{array}$ & 2.50 \\
\hline $\begin{array}{l}\text { 10. The government has no right to require married couples to limit the } \\
\text { number of children they can have. }\end{array}$ & 3.07 \\
\hline As a Whole & $\mathbf{3 . 0 9}$ \\
\hline
\end{tabular}

The computed data revealed that as a whole the attitude toward ecological behavior of employees in terms of attitude toward population growth policies was 3.09 which are uncertain or undecided. Such finding concludes that employees were neither agreeing nor disagreeing to the proposed attitude toward ecological behavior in terms of population growth policy. Such ambivalent attitude indicates that employees may lack of knowledge or correct information about the impact of population growth toward environmental problems.

Table 8. Summary table on Attitude toward ecological behavior

\begin{tabular}{|l|l|}
\hline & Mean \\
\hline Attitude toward human utilization of nature & 3.21 \\
\hline Attitude toward conservation policy & 3.42 \\
\hline Attitude toward population growth policy & 3.09 \\
\hline Overall & 3.24 \\
\hline
\end{tabular}


Texila International Journal of Academic Research

Volume 4, Issue 1, June 2017

Overall evaluation of attitude toward ecological behavior of employees in terms of attitude toward the utilization of nature, conservation policies and population growth policies were at 3.24 which are uncertain or undecided. It revealed that employees had no clear stand or position related to their attitude toward ecological behavior in terms of the utilization of nature and population growth policies. It was only conservation policies that employees agreed to the proposed attitude. However, overall, it really pointed out the fact that employees were ambivalent in relation to their attitude toward ecological behavior proposed in the study. This could be due to ack of knowledge related to the environmental issues and the importance of natural environment.

Problem 3a: What is the environmental behavior of employees of private Catholic school in terms of environmental movement activism?

Table 9. Environmental movement activism

\begin{tabular}{|l|l|}
\hline & Mean \\
\hline $\begin{array}{l}\text { 1. If I get extra income I will donate some money to an } \\
\text { environmental organization. }\end{array}$ & 3.87 \\
\hline $\begin{array}{l}\text { 2. I would like to join and actively participate in an } \\
\text { environmentalist group }\end{array}$ & 3.98 \\
\hline $\begin{array}{l}\text { 3. I don't think I would help to raise funds for environmental } \\
\text { protection. }\end{array}$ & 2.62 \\
\hline 4. I would not get involved in an environmentalist organization. & 2.35 \\
\hline $\begin{array}{l}\text { 5. Environmental protection costs a lot of money. I am prepared } \\
\text { to help out in a fundraising. }\end{array}$ & 3.38 \\
\hline $\begin{array}{l}\text { 6. I would not want to donate money to support an } \\
\text { environmentalist cause. }\end{array}$ & 2.19 \\
\hline 7. I would not go out my way to help recycling campaigns. & 2.31 \\
\hline $\begin{array}{l}\text { 8. I often try to persuade others that the environment is } \\
\text { important. }\end{array}$ & 3.61 \\
\hline 9. I would like to support an environmental organization. & 3.83 \\
\hline $\begin{array}{l}\text { 10. I would never try to persuade others that environmental } \\
\text { protection is important. }\end{array}$ & 2.45 \\
\hline as a whole & $\mathbf{3 . 0 6}$ \\
\hline
\end{tabular}

As it was deduced from the data gathered, the computed mean of environmental behavior of employees in terms of environmental movement activism was at 3.06 which are uncertain or undecided. Based on such average mean, it was concluded that employees were neither agreeing nor disagreeing with the proposed environmental behavior. It showed that employees were ambivalent to the proposed environmental behavior. Such kind of ambivalence could be caused by ignorance of the danger of climate change toward their own life.

Problem 3b: What is the environmental behavior of employees of private Catholic school in terms of personal conservation behaviors?

Table 10. Personal conservation behaviors

\begin{tabular}{|l|l|}
\hline & Mean \\
\hline 1. I could not be bothered to save water or other natural resources. & 2.46 \\
\hline $\begin{array}{l}\text { 2. I make sure that during the winter the heating system in my room is } \\
\text { not switched on too high. }\end{array}$ & 3.36 \\
\hline $\begin{array}{l}\text { 3. In my daily life, I'm just not interested in trying to conserve water } \\
\text { and/or power. }\end{array}$ & 2.32 \\
\hline 4. Whenever possible, I take a short shower in order to conserve water. & 3.52 \\
\hline
\end{tabular}




\begin{tabular}{|l|l|}
\hline 5. I always switch the light off when I don't need it anymore. & 4.08 \\
\hline 6. I drive whenever it suits me, even if it does pollute the atmosphere. & 2.64 \\
\hline 7. In my daily life I try to find ways to conserve water or power. & 4.07 \\
\hline $\begin{array}{l}\text { 8. I am not the kind of person who makes efforts to conserve natural } \\
\text { resources. }\end{array}$ & 2.19 \\
\hline 9. Whenever possible, I try to save natural resources. & 3.94 \\
\hline $\begin{array}{l}\text { 10. Even if public transportation was more efficient than it is, I would } \\
\text { prefer to drive my car. }\end{array}$ & 2.71 \\
\hline as a whole & $\mathbf{3 . 1 3}$ \\
\hline
\end{tabular}

Based on the data collected and computed mean, it was found that as a whole the personal conservation behavior of employees were rated at $\mathbf{3 . 1 3}$ which is uncertain or undecided. Such average mean indicates that employees were neither agreeing nor disagreeing toward the personal conservation behavior for protection of the environment. Such ambivalent behavior concludes that employees did not have much knowledge about the environment and the danger of climate change toward their lives.

Table 11. Summary table on environmental behavior

\begin{tabular}{|l|l|}
\hline & Mean \\
\hline Environmental Movement activism & 3.06 \\
\hline Personal conservation behavior & 3.13 \\
\hline overall & 3.10 \\
\hline
\end{tabular}

Overall, it was found that environmental behaviors of employees were rated at $\mathbf{3 . 1 0}$ which are uncertain or undecided. It concludes that employees were neither agreeing nor disagreeing with proposed environmental behavior. Such behavior indicates that employees may lack of knowledge and information related to the value of natural environment and the danger of climate change.

Problem 4: Is there a relationship between environmental attitude and environmental behavior of Catholic private school employees of Ilocos Sur?

Table 12. Correlations between environmental attitude and environmental behavior

\begin{tabular}{|l|l|l|l|}
\hline & $\begin{array}{l}\text { Environmental } \\
\text { Movement activism }\end{array}$ & $\begin{array}{l}\text { personal } \\
\text { conservation } \\
\text { behavior }\end{array}$ & $\begin{array}{l}\text { overal } \\
1\end{array}$ \\
\hline $\begin{array}{l}\text { Anthropocentric concern } \\
\text { attitude }\end{array}$ & -.064 & .035 & -.015 \\
\hline $\begin{array}{l}\text { human dominance over } \\
\text { nature attitude }\end{array}$ & $.123^{* *}$ & $.115^{* *}$ & $.145^{* *}$ \\
\hline Eco-centric attitude & $.240^{* *}$ & $.197^{* *}$ & $.265^{* *}$ \\
\hline Overall & $.107^{* *}$ & $.148^{* *}$ & $.156^{* *}$ \\
\hline
\end{tabular}

**. Correlation is significant at the 0.01 level (2-tailed).

It was found that overall; there was a significant correlation at the 0.01 level (2-tailed) between environmental attitude and environmental behavior. Such significant correlation indicates that environmental attitudes affect the environmental behavior of employees. However, it was also found that anthropocentric attitude did not have a significant correlation with environmental movement activism and personal conservation policies.

Problem 5: Is there a relationship between environmental attitude and attitude toward utilization of nature, personal conservation behavior and population growth policy? 
Texila International Journal of Academic Research

Volume 4, Issue 1, June 2017

Table 13. Correlations between environmental attitude and attitude toward utilization of nature, personal conservation behavior and population growth policy

\begin{tabular}{|l|l|l|l|l|}
\hline & $\begin{array}{l}\text { Attitude toward } \\
\text { human utilization } \\
\text { of nature }\end{array}$ & $\begin{array}{l}\text { Personal } \\
\text { conservatio } \\
\text { n Behavior }\end{array}$ & $\begin{array}{l}\text { Population } \\
\text { growth policy }\end{array}$ & Overall \\
\hline $\begin{array}{l}\text { Anthropocentric } \\
\text { Concern attitude }\end{array}$ & $.138^{* *}$ & $.338^{* *}$ & $.090^{*}$ & $.267^{* *}$ \\
\hline $\begin{array}{l}\text { human dominance } \\
\text { over nature }\end{array}$ & $.322^{* *}$ & $.155^{* *}$ & $.279^{* *}$ & $.343^{* *}$ \\
\hline $\begin{array}{l}\text { Eco-centric } \\
\text { attitude }\end{array}$ & $.410^{* *}$ & $.231^{* *}$ & $.287^{* *}$ & $.422^{* *}$ \\
\hline overall & $.393^{* *}$ & $.363^{* *}$ & $.301^{* *}$ & $.486^{* *}$ \\
\hline
\end{tabular}

**. Correlation is significant at the 0.01 level (2-tailed).

*. Correlation is significant at the 0.05 level (2-tailed).

Deduced from the computed data, it was found that overall, there was a significant correlation between environmental attitude and attitude toward utilization of nature, personal conservation behavior and population growth policy at the 0.01 level (2-tailed) and at the 0.05 level (2-tailed). Such significant correlation means that environmental attitudes affect how humans utilize the natural environment, personal conservation behavior and their support to the population growth policy.

Problem 6: Is there a relationship between attitude toward ecological behavior and environmental behavior?

Table 14. Correlations between attitude toward ecological behavior and environmental behavior

\begin{tabular}{|l|l|l|l|}
\hline & $\begin{array}{l}\text { Environmental } \\
\text { movement activism }\end{array}$ & $\begin{array}{l}\text { personal } \\
\text { conservation } \\
\text { behavior }\end{array}$ & overall \\
\hline $\begin{array}{l}\text { Attitude toward human } \\
\text { utilization of nature }\end{array}$ & $.231^{* *}$ & $.242^{* *}$ & $.288^{* *}$ \\
\hline $\begin{array}{l}\text { Attitude toward conservation } \\
\text { policies }\end{array}$ & $.170^{* *}$ & $.227^{* *}$ & $.243^{* *}$ \\
\hline $\begin{array}{l}\text { Attitude toward population } \\
\text { growth policy }\end{array}$ & $.373^{* *}$ & $.166^{* *}$ & $.323^{* *}$ \\
\hline overall & $.356^{* *}$ & $.292^{* *}$ & $.392^{* *}$ \\
\hline
\end{tabular}

Based on the data gathered, overall, it was found that there was a significant correlation at the 0.01 level (2-tailed) between attitude toward ecological behavior and environmental behavior. Such significant correlation concludes that attitude toward ecological behavior influences the environmental behavior.

\section{Conclusion}

Based on the presentation, analysis and findings, the study concludes that overall the employees were uncertain related to their environmental attitude and environmental behavior and their attitudes toward environment have a significant correlation with the environmental behavior. Thus, the hypothesis of the study that there is a significant relationship between environmental attitude and environmental behavior is accepted. 


\section{Recommendation}

Based on the findings and conclusion, the study recommends that in order to improve attitude toward environmental and environmental behavior of employees, the school needs to include environmental training or seminar to the employees. Beside the employees, it is also recommended that it is already time to include environmental ethics in the curriculum.

\section{References}

[1]. Ajzen, I. (1991). The theory of planned behavior Organizational Behavior and Human Decision Processes, 50, 179-211

[2]. Amstrong, W. R. (1996). The Relationship between Culture and Perception of Ethical Problems in International Marketing, Journal of Business Ethics Volume: 15, Issue: 11, Pages: 1199-1208

[3]. Annenberg, L. (n.d). Population Growth and Environment. Retrieved from

https://www.learner.org/courses/envsci/unit/text.php?unit=5\&secNum=5

[4]. Bandura A. (1986). Social Foundations of Thought and Action: A Social Cognitive Theory. Englewood Cliffs NJ: Prentice-Hall

[5]. Bem, D.J. (1970). Beliefs, attitudes and human affairs. Belmont, California: Brooks/Cole.

[6]. Becker, G. K. (2009). Environmental Ethics: Intercultural Perspectives. New York: Value Inquiries Book Series (vibs)

[7]. Bostwana Environmental Information System. (n.d). Policies: National Policies on Natural Resources Conservation and Development. Retrieved from

http://www1.eis.gov.bw/EIS/Policies/Lists/Legislation/DispForm.aspx?ID=8

[8]. Bricker, K. W. (2009). Ten Commandments for the Environment. Manila: Paulines Publishing House

[9]. Conservation Breeding Specialist Group. (n.d). Measuring the Impact of Human Behavior on Conservation Efforts. Retrieved from http://www.cbsg.org/blog/201310/measuring-impact-humanbehavior-conservation-efforts

[10]. Daily Inquirer. (2017). Trump Exec Says CO2 Not Global Warming Cause, Vol. 32, No. 93, p A 8.

[11]. Donald, M. (2002).A Mind So Rare: The Evolution of Human Consciousness. New York: W.W. Norton \& Company, Inc.

[12]. Eilam, E \& Trop, T. (2012). Environmental Attitudes and Environmental Behavior-which is the Horse and which is the Cart? School of Education, Institute of Sustainability and Innovation (ISI), Victoria University. Retrieved from http://www.mdpi.com/journal/sustainability.

[13]. Encyclopedia.com. (n.d). Environmental Movement. Retrieved from $\mathrm{http}: / / \mathrm{www}$.encyclopedia.com/earth-and-environment/ecology-and-environmentalism/environmentalstudies/environmental-movement

[14]. EPA. (2016). Climate Impact on Human Health. Retrieved from https://www.epa.gov/climateimpacts/climate-impacts-human-health

[15]. Fishbein, M. \& Ajzen, I. (1975).

[16]. Belief, attitude, intention and behavior: An introduction to theory and research. Reading, Mass.: Addison Publishing Company. Gale Encyclopedia of Science. (2008). Anthropocentrism. retrieved from http://www.encyclopedia.com/history/modern-europe/czech-and-slovak-history/anthropocentrism [17]. Gibson, K. R. (2002). "Customs and cultures in animals and humans: Neurobiological and evolutionary considerations." Anthropological Theory 2.3 (2002): 323-339.

[18]. Gifford, R \& Sussman, R. (2012). Environmental Attitude. The Handbook of the Environmental and Conservation Psychology. Retrieved from

http://www.oxfordhandbooks.com/view/10.1093/oxfordhb/9780199733026.001.0001/oxfordhb-

9780199733026-e-4?rskey=iDunuP\&result=1

[19]. Glanz K, Rimer B.K, Viswanath K., eds. (2008). Health Behavior and Health Education: Theory, Research, and Practice (4th ed). San Francisco: Jossey-Bass

[20]. Haberlein, A. T. (n.d). Environmental Attitude. College of Agriculture and Life, University of Wisconsin. Retrieved from http://dces.wisc.edu/wpcontent/uploads/sites/30/2013/08/EnvironmentalAttitudes.pdf. 
Texila International Journal of Academic Research

Volume 4, Issue 1, June 2017

[21]. Hadfield, L. (2009). Environmental Ethics and Justice, edited by Estelle L. Weber. Oxford, United Kingdom: Inter-Disciplinary Press

[22]. Hines, J. M., Hungerford, H. R., \& Tomera, A. N. (1987). Analysis and synthesis of research on responsible environmental behavior: A meta-analysis. Journal of Environmental Education, 18(2), 1-8.

[23]. Hoffman, B. (2015). The 5 most powerful self-beliefs that ignite human behavior. https://www.elsevier.com/connect/the-5-most-powerful-self-beliefs-that-ignite-human-behavior.

Retrieved, July 28, 2016.

[24]. Hunt, D. S \& Vitell, J. S (1986). The General Theory of Marketing Ethics: A Revision and Three Questions Retrieved from

http://sdh.ba.ttu.edu/JMacro06\%20-\%20A\%20general\%20theory\%20of\%20marketing\%20ethics-

A\%20revision\%20and\%20three\%20questions--PAGE\%20PROOFS.pdf.

[25]. Internet Encyclopedia of Philosophy. (n.d). Environmental Ethics. Retrieved from http://www.iep.utm.edu/envi-eth/

[26]. Jarreau, B. (2014). The Psychology of Environmental Behavior that you're ignoring in Your Writing. http://www.scilogs.com/from_the_lab_bench/the-psychology-of-environmental-behavior-thatyoure-ignoring-in-your-writing/. Retrieved, July 20, 2016

[27]. Johansson, U. (2012). Toward A Bio-centric Attitude in Environmental Education. Master Thesis, Linnéuniversitet.

[28]. Kalantari, K., Shabanali, F. H., Asadi, A. \& Mohamadi, H. M. (2007). Investigating Factors Affecting Environmental Behavior of Urban Residents: A Case Study in Tehran City- Iran. University of Tehran, Karaj - Iran. American Journal of Environmental Sciences 3 (2): 67-74, 2007.

[29]. Kaiser, F. G., Wölfing, S., \& Fuhler, U. (1999). Environmental attitude and ecological behavior. Journal of Environmental Psychology, 19, 1-19

[30]. Kaiser, G. F., Ranney, M., Hartig, H. T. \& Bowler A. Peter. (1999). Ecological Behavior, Environmental Attitude and Feeling of Responsibility for the Environment. Swiss Federal Institute of Technology (ETH), Zurich, Switzerland, University of California, Berkeley, USA, Uppsala University, Sweden, University of California, Irvine, USA. European Psychologist, Vol. 4, No. 2, June 1999. Hogrefe \& Huber Publishers

[31]. Kaiser, G. F.Ranney, M., Hofstetter, P. \& Doka, G. (2003). Ecological Behavior and Its Environmental Consequences: a life cycle assessment of a self-report measure. Department of Technology Management, Eindhoven University of Technology, Eindhoven, The Netherlands, Doka Environmental-Life-Cycle-Assessments, Zurich, Switzerland, School of Public Health, Harvard University, Boston, MA, USA, Graduate School of Education, University of California, Berkeley, CA, USA Journal of Environmental Psychology 23 (2003) 11-20.

[32]. KECMANOVIC, D. (1969). The paranoid attitude as the common form of social behavior. Sociologija, 11(4), 573-585. Retrieved from $\mathrm{http} / / /$ search.proquest.com/docview/60877639?accountid=12347 (registration required)

[33]. Kirk, J.L. (2010). Sustainable Environment and Pro-Environmental Behaviors. Master Thesis, University of Nebraska.

[34]. Kortenkamp, V. Katherine \& Moore, F. Colleen. (2001), University of Wisconsin, Madison. Retrieved from http://psych.wisc.edu/moore/PDFsMyPapers/Kortenkamp\%26Moore2001.pdf

[35]. Maloney, M. P., \& Ward, M. P. (1973). Ecology: Let's hear it from the people - An objective scale for measurement of ecological attitudes and knowledge. American Psychologist, 28, 583-586.

[36]. Martine B. \& Kerry, B. eds. (1992). Buddhism and Ecology (London, UK: Cassell Publishers Limited.

[37]. Milfont, L. T. \& John D. J. (2006). Preservation and Utilization: Understanding the Structure of Environmental Attitudes. University of Auckland, New Zealand. Federal University of Alagoas, Brazil. University of Auckland, New Zealand

[38]. Monda, P. (n.d). Effects of Population Growth on Environment. Retrieved from http://www.yourarticlelibrary.com/essay/effects-of-population-growth-on-our-environment/39624/

[39]. Montague, P. (2012). Why is The Environmental Movement not winning Retrieved from http://www.huffingtonpost.com/peter-montague/green-initiatives_b_1301418.html 
[40]. Nalukenge, H. (2009). Environmental Ethics is Key to Sustainability in a Contemporary Society. United Kingdom: The Inter-Disciplinary Press

[41]. National Park Service. (n.d). Conservation VS Preservation and National Park Service. Retrieved from https://www.nps.gov/klgo/learn/education/classrooms/conservation-vs-preservation.htm

[42]. Oskamp, S. (2000). A sustainable future for humanity? How can psychology help? American Psychologist, 55, 496-508.

[43]. Pew Forum on Religion and Public Life. (2012). "Nones' on the Rise: One-in-Five Adults Have No Religious Affiliation". Retrieved from https://www.pew.com

[44]. Planas, F. (n.d) "The Exploitation of Natural Resources". Un An Pour La Planete. Retrieved 6 April, 2017

[45]. Paul T. (1986). Respect for Nature: A Theory of Environmental Ethics. Princeton, N.J.: Princeton University Press.

[46]. Pierce, J. C., \& Lovrich, N. P. (1980). Belief systems concerning the environment: The general public, attentive publics, and state legislators. Political Behavior, 2, 259-286.

[47]. Poortinga, W., Steg, L., \& Vlek, C. (2002). Environmental risk concern and preferences for energy-saving measures. Environment and Behavior, 34, 455-478.

[48]. Racelis, A. R. (2009). Relationship between Employee Perceptions of Corporate Ethics and Organizational Culture: An Exploratory Study. College of Business Administration, University of the Philippines, Philippines.http://apmr.management.ncku.edu.tw/comm/updown/DW1006213442.pdf

[49]. Roach, M. C. (2003). Mother/Nature: Popular Culture and Environmental Ethics. Bloomington \& Indianapolis: Indiana University Press.

[50]. Rowe, S. J. (1994). "Eco-centrism: the Chord that Harmonizes Humans and Earth." The Trumpeter 11 (2): 106-107.

[51]. Sawitri, R. D. Hadiyanto, H. \& Hadi, P. S. (2014). Pro-Environmental Behavior from a Social Cognitive Theory Perspective. Procedia Environmental Science Journal. http://www.sciencedirect.com. Retrieved, July 27, 2016.

[52]. Schultz, P. W., Shriver, C., Tabanico, J. J., \& Khazian, A. M. (2004). Implicit connections with nature. Journal of Environmental Psychology, 24, 31-42.

[53]. Schinkel, A. (2009). State Neutrality and Compulsory Environmental Education. Environmental Ethics: Sustainability and Education. Oxford, United Kingdom: Inter-Disciplinary Press.

[54]. Singh, N. \& Gupta, K. (2013). "Environmental attitude and ecological Behavior of Indian consumers", Social Responsibility Journal, Vol. 9 ISS: 1, pp.4 - 18

[55]. Scott, D. \& Willits, K. F. (1994). Environmental Attitudes and Behavior: A Pennsylvania Survey. Pennsylvania State University. Sage Journals of Environment and Behavior

[56]. Spilka, B., \& McIntosh, D. N. (1996). The psychology of religion. West view Press.

[57]. Spirkin, A. (2016). Man in the Realm of Nature, in the Dialectical Materialism. Retrieved from https://www.marxists.org/reference/archive/spirkin/works/dialectical-materialism/ch05-s03.html

[58]. Stern, P. C., Dietz, T., Kalof, L., \& Guagnano,G. A. (1995). Values, beliefs, and proenvironmental action: Attitude formation toward emergent attitude objects. Journal of Applied Social Psychology, 25, 1611-1636.

[59]. Tangney, J. P., Stuewig, J., \& Mashek, D. J. (2007). Moral emotions and moral behavior. Annual Review of Psychology, 58, 345.

[60]. Thompson, S. C. G., \& Barton, M. A. (1994). Ecocentric and anthropocentric attitudes toward the environment. Journal of Environmental Psychology, 14, 149-157.

[61]. Triandis, H. C. (1994). Culture and social behavior. New York: McGraw-Hill Book Company

[62]. Tylor, E.B. (1874). Primitive culture: researches into the development of mythology, philosophy, religion, art, and custom. Retrieved from http://www.oocities.org/mravikiran/culsoc.html

[63]. Vlek, Charles \& Steg, Linda. (2007). Human behavior and Environmental Sustainability: Problems, Driving Force, and Research Topics, in Journal of Social issues 63 (1), 1-19, University of Groningen

[64]. Weber, L. E. (2009). Indigenous Land Management in a Modern World:

[65]. A Case Study from Papua New Guinea. Environmental Ethics: Sustainability and Education. Oxford, United Kingdom: Inter-Disciplinary Press 
Texila International Journal of Academic Research

Volume 4, Issue 1, June 2017

[66]. White, L. (2008). The Historical Roots of Our Ecological Crisis. Edited by Louis Podjman. Belmont, CA: Thomson Wadsworth

[67]. WHO. (2016). Climate Change and Health, Fact Sheets. Retrieved from

http://www.who.int/mediacentre/factsheets/fs266/en/.

[68]. Wilson, E.O. (1975). "Man: From Sociobiology to Sociology" in Sociobiology. Cambridge, MA: Harvard University Press

[69]. Wright, R. (1994). The Moral Animal Why We Are The Way We Are: The New Science Of Evolutionary Psychology. New York, NY: Vintage Books.

[70]. WYER, R. S. J. (1965). Effect of child-rearing attitudes and behavior on children S responses to hypothetical social situations. Journal of Personality and Social Psychology, 2(4), 480-486. 